\title{
PENERAPAN TEORI DISKURSUS HABERMAS SEBAGAI ALTERNATIF PENYELESAIAN SENGKETA
}

\author{
Tri Harnowo* \\ Universitas Prasetiya Mulya \\ BSD City Kavling Edutown I.1, Jl. BSD Raya Utama, BSD City, \\ Kec. Pagedangan, Tangerang, Banten 15339
}

\begin{abstract}
According to Habermas's discourse theory, communicative actions justified through validity claim can build a common understanding and social collaboration. Mediation is one form of dispute resolution through a negotiation process to obtain a mutual agreement facilitated by a neutral third party oriented to common interests by maintaining good relations between the parties in the future. Communication techniques such as listening actively, asking questions, and reframing statements are important skills that mediators must possess. This conceptual paper analyzes the interaction between Habermas's discourse theory and the concept of mediation. Habermas's discourse theory can be a basic framework of analysis for mediators to predict the creation of consensus, identify statements based on validity claims, and search for common understanding options.
\end{abstract}

Keywords: Habermas, discourse theory, communication thetory, alternative dispute resolution, mediation.

\section{Intisari}

Menurut teori diskursus Habermas, tindakan komunikatif yang dijustifikasi melalui klaim kesahihan dapat membangun suatu pemahaman bersama dan kerjasama sosial. Mediasi merupakan salah satu bentuk penyelesaian sengketa melalui proses perundingan untuk memperoleh kesepakatan bersama difasilitasi oleh pihak ketiga netral yang berorientasi pada kepentingan bersama dengan menjaga hubungan baik para pihak di masa mendatang. Teknik komunikasi seperti mendengar aktif, bertanya, dan membingkai ulang pernyataan merupakan keahlian penting yang harus dimiliki oleh mediator. Artikel ini menganalisis interaksi antara teori diskursus Habermas dan penerapannya dalam teknik mediasi. Teori diskursus Habermas dapat menjadi kerangka dasar analisis bagi mediator untuk memprediksi terciptanya konsensus, mengidentifikasi pernyataan-pernyataan berdasarkan klaim kesahihan dan mencari opsi-opsi kesepakatan bersama.

Kata Kunci: Habermas, teori diskursus, teori komunikasi, alternatif penyelesaian sengketa, mediasi.

\section{Pokok Muatan}

A. Pendahuluan 56

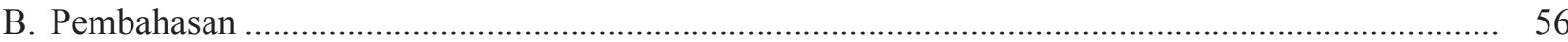

1. Persinggungan Antara Teori Diskursus Habermas dan Alternatif Penyelesaian Sengketa........... 56

2. Penerapan Teori Diskursus Habermas Dalam Mediasi ............................................................... 60

C. Penutup

Alamat korespondensi: tri.harnowo@pmbs.ac.id 


\section{A. Pendahuluan}

Jürgen Habermas, seorang filsuf dan teoritisi sosial dilahirkan di Kota Dusseldorf, Jerman pada tanggal 18 Juni 1929. Ia adalah generasi kedua dari Mazhab Frankfurt, dan penerus dari teori kritis yang ditawarkan pendahulunya, Max Horkheimer, Theodor Adorno, dan Herbert Marcuse. Teori kritis, yang dilahirkan oleh Mazhab Frankfurt, memiliki maksud membuka seluruh selubung ideologis dan irasionalisme yang telah melenyapkan kebebasan dan kejernihan berpikir manusia modern. ${ }^{1}$ Teori kritis menentang sistem filosofi yang tertutup, yang kemudian mengubahnya menjadi metode dialektis yang diterapkan pada fenomena sosial. ${ }^{2}$ Jürgen Habermas menambahkan konsep komunikasi di dalam teori kritis. ${ }^{3}$ Menurut Habermas, komunikasi dapat menyelesaikan kemacetan teori kritis. Habermas membedakan pekerjaan dan komunikasi (interaksi). Pekerjaan merupakan tindakan instrumental, jadi sebuah tindakan yang bertujuan untuk mencapai sesuatu. Sedangkan komunikasi adalah tindakan saling pengertian. Dalam tradisi Mazhab Frankfurt, teori dan praksis tidak dapat dipisahkan. ${ }^{4}$ Praksis dilandasi oleh kesadaran rasional, dimana rasio tidak hanya tampak dalam kegiatan-kegiatan yang berkerja terus menerus, melainkan interaksi dengan orang lain menggunakan bahasa sehari-hari.

Mediasi adalah salah satu bentuk penyelesaian sengketa melalui proses perundingan untuk memperoleh kesepakatan para pihak dengan dibantu oleh pihak ketiga, yaitu mediator yang bertugas memfasilitasi para pihak dalam mencapai kesepakatan bersama. Pada dasarnya, mediasi berorientasi pada kepentingan bersama dengan menjaga hubungan baik para pihak di masa mendatang. Mediasi akan berhasil apabila dalam negosiasi para pihak mengedepankan kepentingan bersama (interest based), tidak berdasarkan hanya mempertahankan posisinya (positional based). Komunikasi merupakan salah satu keahlian penting yang harus dimiliki oleh mediator. Sebagian besar peran mediator dalam proses mediasi adalah mendengar, bertanya, mengklarifikasi, dan membingkai ulang pernyataan (reframing), yang kesemuanya demi terciptanya kondisi yang kondusif dalam bermediasi.

Menurut penjelasan sebagaimana diuraikan di atas, nampak titik singgung antara teori diskursus Habermas dan mediasi, dimana keduanya berorientasi pada konsensus atau kesepakatan bersama, sehingga penulis tertarik untuk mengkaji bagaimana penerapan teori diskursus Habermas sebagai alternatif penyelesaian sengketa pada umumnya yang dapat diterapkan sebagai kerangka kerja suatu bentuk alternatif penyelesaian seperti mediasi. Pertimbangan penggunaan teori diskursus Habermas adalah untuk mengidentifikasi persamaan konsepsi antara teori diskursus Habermas dan alternatif penyelesaian sengketa sehingga hasilnya dapat digunakan sebagai kerangka kerja suatu alternatif penyelesaian sengketa.

\section{B. Pembahasan}

\section{Persinggungan Antara Teori Diskursus Habermas dan Alternatif Penyelesaian Sengketa}

Menurut pandangan Habermas, filsafat harus memiliki hubungan dan bekerjasama dengan disiplin ilmu lainnya seperti ilmu sosial dan ilmu empiris pada umumnya. Keterkaitan antara filsafat dengan ilmu empiris dihadirkan dalam bukunya "Theory of Communicative Action". Rekonstruksi kritis Habermas terhadap permasalahan rasionalitas mengambil akarnya dari teori kritis tentang kritik terhadap rasio instrumental. ${ }^{5}$ Bagi Habermas, 
rasionalitas tidak melulu milik pengetahuan tertentu, tetapi lebih pada bagaimana subjek berbicara dan bertindak memperoleh dan menggunakan pengetahuan. ${ }^{6}$ Teori tindakan komunikatif merekonstruksi rasionalitas dengan menggunakan bahasa sebagai fondasi, yang disebut dengan "sikap performatif" bahasa. Bahasa adalah salah satu media untuk tindakan koordinasi. Koordinasi melalui bahasa menuntut para penutur untuk mengadopsi sikap praksis yang berorientasi pada pencapaian pemahaman bersama atau konsensus yang merupakan tujuan melekat dari suatu tuturan (speech). Ketika para penutur satu sama lain menggunakan sikap praksis semacam ini, mereka melakukan apa yang disebut dengan tindakan komunikatif (communicative action). Dengan demikian di sini Habermas merekonstruksi konsep rasio praktis menjadi konsep rasio komunikatif.

Habermas meyakini bahwa tindakan antar manusia dalam sebuah masyarakat tidak terjadi secara semena-mena, melainkan bersifat rasional. Sifat rasional tindakan tersebut dalam pandangan Habermas bersifat instruktif. Ia mengasumsikan bahwa para partisipan dalam komunikasi mengorientasikan diri pada pencapaian pemahaman satu sama lain. Pemahaman berarti mengerti suatu ungkapan bahasa. Pemahaman juga dapat diartikan sebagai persetujuan atau konsensus. Rasio komunikatif membimbing tindakan komunikatif untuk mencapai persetujuan bersama berupa konsensus tentang sesuatu. Konsensus tersebut tidak serta merta terjadi begitu saja. Prasyarat utama terjadinya konsensus adalah adanya saling mengerti dan adanya pinjam-meminjam perspektif. Satu pihak harus mencoba memahami persoalan orang lain atau mencoba berperan sebagai yang lain agar mengetahui persoalan yang dihadapi orang lain.

Konsensus, dengan demikian, dicapai untuk menyelesaikan suatu sengketa. Sengketa menurut Dean G. Pruitt dan Jeffrey Z. Rubin diartikan sebagai persepsi mengenai perbedaan kepentingan (perceived divergence of interest), atau suatu keyakinan bahwa aspirasi pihak-pihak yang bersengketa tidak dicapai secara simultan karena adanya perbedaan kepentingan. ${ }^{7}$ Sementara John G. Merrills memahami suatu persengketaan sebagai terjadinya perbedaan pemahaman akan suatu keadaan atau obyek yang diikuti oleh pengklaim oleh satu pihak dan penolakan di pihak lainnya. ${ }^{8}$ Richard L. Abel, memaknai sengketa sebagai pernyataan publik mengenai tuntutan yang tidak selaras (inconsistent claim) terhadap sesuatu yang bernilai karena aspek ketidaksesuaian para pihak tentang sesuatu yang bernilai. ${ }^{9}$ Adapun Laura Nader dan Harry F. Todd Jr., mengartikan sengketa sebagai keadaan apabila sengketa tersebut dinyatakan di muka atau dengan melibatkan pihak ketiga. ${ }^{10}$

Dari beberapa pandangan di atas dapat ditarik kesimpulan penyebab atau sumber timbulnya sengketa atau konflik, yaitu adanya ketidakadilan atau perasaan tidak adil, pelanggaran hak, perlakuan yang salah, perbedaan kepentingan dan perbedaan pemahaman. Beberapa sarjana seperti Ralf Dahrendorf, Dian G. Pruitt, Jeffrey Z. Rubin, Simon Fisher, Laura Nader, dan Harry F. Todd Jr., berpandangan bahwa teori penyelesaian sengketa berorientasi pada struktur dan institusi sosial. ${ }^{11}$ Masyarakat mempunyai dua wajah, yaitu sengketa dan konsensus. Oleh karena itu teori sosiologi harus dibagi menjadi dua, yaitu teori sengketa dan teori konsensus. Teori sengketa menganalisis sengketa

\footnotetext{
Jürgen Habermas, 1984, Theory of Communicative Action, Volume One: Reason and the Rationalization of Society, diterjemahkan oleh Thomas A. McCarthy, Boston, Massachuset, Beacon Press, hlm. 11.

Salim H.S. dan Erlies Septiana Nurbani, 2013, Penerapan Teori Hukum pada Penelitian Tesis dan Disertasi, Raja Grafindo, Jakarta, hlm. 136. John G. Merrills, 1991, International Dispute Settlement, Penterjemah Achmad Fausan, Penyelesaian Sengketa Internasional, Tarsito, Bandung, hlm. 1.

9. Lawrence M. Friedman, 2009, Sistem Hukum Perspektif Ilmu Sosial, (A Legal System a Social Science Perspective), diterjemahkan oleh M. Khozim, Nusa Media, Bandung, hlm. 11.

10 Valerine J.L. Kriekhoff, dalam Salim HS dan Erlies Septiana Nurbani, 2013, Loc. cit..

$11 \quad$ Ibid., hlm. 144.
} 
kepentingan dan penggunaan kekerasan yang mengikat masyarakat bersama di hadapan tekanan hukum. Sedangkan teori konsensus menguji nilai integrasi dalam masyarakat.

Alternatif Penyelesaian Sengketa (APS) atau Alternative Dispute Resolution timbul dari suatu gerakan. Besarnya biaya berlitigasi mengakibatkan tingginya biaya ekonomi, kelelahan psikis yang berkepanjangan, ditambah dengan biaya asuransi, dan sia-sianya waktu yang dihabiskan untuk berperkara. Pada tahun 80-an, Presiden Bush Senior mengkritik para pengacara tidak memiliki sensitivitas terhadap "access to justice.${ }^{12}$ Kepiawaian hukum dijadikan alat untuk memanipulasi klien dalam sistem hukum yang ada, yang pada ujungnya adalah untuk memperkaya diri sendiri. Demikian jenuhnya hingga melampaui titik kulminasinya, melahirkan arus balik yang mengarah pada upaya menjauh dari sistem adversarial. ${ }^{13}$ Mediasi, sebagai salah satu bentuk dari alternatif penyelesaian sengketa merupakan manifestasi dari konsesp akses ke keadilan (access to justice). ${ }^{14}$ Berkembangkan konsep access to justice adalah untuk menjawab kritik terhadap proses peradilan atau litigasi yang hasilnya semakin menjauh dari rasa keadilan masyarakat. Mauro Cappelletti and Bryant Garth merupakan penggagas utama access to justice menempatkan mediasi yang merupakan salah satu bentuk alternatif penyelesaian sengketa sebagai gelombang ketiga dari akses ke keadilan. ${ }^{15}$

Teori tindakan komunikatif Habermas bertumpu pada gagasan bahwa tatanan sosial pada akhirnya tergantung pada kapasitas para aktor untuk mengenali validitas atau kesahihan intersubjektif dari berbagai klaim yang menjadi dasar kerja sama sosial. Dengan demikian, kerja sama melalui tindakan komunikatif diperoleh dengan klaim kesahihan yang dapat dijustifikasi melalui komunikasi termasuk dengan cara mengkritisi. Teori tindakan komunikatif bergantung pada justifikasi, yaitu teori argumentasi atau diskursus. Oleh karenanya, diskursus oleh Habermas disebut sebagai "bentuk reflektif" dari tindakan komunikatif.

Suatu hasil dalam diskursus, baik konsensual dan non-konsensual, adalah rasional hanya jika dalam prosesnya tidak terjadi eksklusi yang kasat mata, penindasan argumentasi, manipulasi, penipuan diri, dan sejenisnya. ${ }^{16}$ Seorang pengamat netral dapat menilai apakah lawan bicara telah mematuhi prosedur institusional, sedangkan peserta yang terlibat harus menilai seberapa baik mereka telah memenuhi pra-syarat dialektika dengan pengujian kritis yang ketat. Kondisi kebenaran

12 Emmy Yuhassarie, (ed.), 2005, Mediasi dan Court Annexed Mediation, Pusat Pengkajian Hukum, Jakarta, hlm. xix.

3 Sistem adverserial berlaku di negara common law. Sistem ini menempatkan hakim sebagai wasit yang memutuskan perkara berdasarkan bukti-bukti yang dikemukakan oleh para pihak dan hukum yang berlaku. Di sini kepiawaian pengacara dalam berargumentasi menjadi kunci pemenangan suatu perkara. Hakim boleh, tetapi jarang, mengajukan pertanyaan kepada saksi-saksi. Hal ini berbeda dengan sistem inquisitoir yang dianut negara civil law atau Eropa kontinental mewajibkan keterlibatan yang lebih aktif dari seorang hakim. Di sistem inquisitor yang dianut di beberapa negara, pengacara harus mengajukan pertanyaan kepada saksi melalui hakim.

14 Penggolongan mediasi sebagai alternatif penyelesaian sengketa bukan tanpa kontroversi perdebatan terutama terkait dengan istilah "alternatif" untuk mediasi yang seolah-olah menunjukan bahwa lembaga mediasi merupakan lembaga baru yang ada setelah lembaga peradilan. Di dunia timur pola penyelesaian dengan musyawarah adalah suatu hal yang biasa dan lembaga penyelesaian sengketa ini mendahului model litigasi peradilan yang berasal dari Barat. Emmy Yuhassarie mengungkapkan mediasi mungkin secara formal merupakan suatu hal yang ralatif baru dengan diundangkannya Undang-Undang No. 30 Tahun 1999 tentang Arbitrasi dan Alternatif Penyelesaian Sengketa, namun pola penyelesaian seperti mediasi di Indonesia sudah ada sejak dulu. Para peneliti antropologi maupun sosiologi telah mencatat dalam berbagai hasil studi mereka bahwa praktek adanya pihak ketiga sebagai penengah dan mendamaikan para pihak yang bersengketa telah ada sejak jaman pedesaan terbentuk, atau meminjam istilah anthropologi, sejak masyarakat komunal adat terbentuk. Menurut Leopold Pospisil, seorang antropolog, misalnya, pola penyelesaian konflik antara warga komunal tersebut, meliputi konflik domestik seperti masalah keluarga, pertetanggaan, tanah ulayat, warisan dan bahkan antar kelompok acapkali diajukan ke tetua adat atau pemuka-pemuka agama yang disegani untuk dicarikan petunjuk penyelesaiannya. Lihat Emmy Yuhassarie (ed.), 2003, Arbitrase dan Mediasi, Pusat Pengkajian Hukum, Jakarta, hlm. v.

15 Gelombang pertama legal aid for the poor ditandai dengan kebijakan pro-bono lawyer; Gelombang kedua adalah representation for diffuse interest ditandai dengan kebijakan gugatan perwakilan atau class action; Gelombang ketiga adalah broader concept of access to justice berupa gerakan alternatif penyelesaian sengketa dimana mediasi termasuk salah satu di dalamnya. Lihat Mauro Cappelletti, et. al., "Access To Justice: Comparative General Report", International Private Law, 1976, hlm. 682-715.

16 James Bohman dan William Rehg, "Jürgen Habermas", https://plato.stanford.edu/archives/fall2017/entries/habermas/, diakses 9 Januari 2019. 
dari proposisi adalah adanya persetujuan potensial dari semua. Dengan demikian makna universalpragmatis kebenaran ditentukan oleh tuntutan untuk mencapai konsensus rasional. ${ }^{17}$

Emmy Yuhassarie mengemukakan mediasi sebagai alternatif penyelesaian sengketa memiliki karakteristik sekaligus keungggulan sebagai berikut: ${ }^{18}$

a. Voluntary: keputusan untuk bermediasi diserahkan kepada kesepakatan para pihak, sehingga dapat dicapai suatu putusan yang benar-benar merupakan kehendak dari para pihak;

b. Informal/flexible: tidak seperti dalam proses litigasi (pemanggilan saksi, pembuktian, replik, duplik dan sebagainya), para pihak dengan bantuan mediator dapat mendesain atau menyesuaikan sendiri prosedur bermediasi;

c. Interest based: dalam mediasi tidak dicari siapa yang benar atau salah, tetapi lebih untuk menjaga kepentingan-kepentingan masingmasing pihak;

d. Future looking: karena lebih menjaga kepentingan masing-masing pihak, mediasi lebih menekankan untuk menjaga hubungan para pihak yang bersengketa ke depan, tidak berorientasi ke masa lalu;

e. Parties oriented: dengan prosedur yang informal, maka para pihak yang berkepentingan dapat secara aktif mengontrol proses mediasi dan pengambilan penyelesaian tanpa terlalu bergantung kepada pengacara; dan

f. Parties'control: penyelesaian sengketa melalui mediasi merupakan keputusan dari masing-masing pihak.
Menurut pandangan di atas dapat disimpulkan bahwa prosedur dalam mediasi bersifat informal dan bisa dibuat fleksibel sesuai keinginan para pihak. Mediator dapat menyarankan suatu prosedur yang sesuai dengan sifat sengketa yang bersangkutan dan cocok dengan hubungan yang ada antara para pihak. Hal senada diungkapkan oleh Husseyn Umar yang mengemukakan kelebihan dari mediasi, bahkan jika dibandingkan dengan arbitrase, yaitu: ${ }^{19}$

1) para pihak terlibat aktif dalam proses penyelesaian sengketa menuju hasil/ persetujuan yang diupayakan (bandingkan dengan arbitrase yang bersifat adversarial atau mempertentangkan posisi dan kepentingan para pihak secara hukum dengan prosedur yang legalistik);

2) sifatnya sukarela, dan informal tanpa rasa tertekan dan informal;

3) proses mencapai penyelesaian bisa cepat dan murah biaya (yang dalam hal tertentu arbitrase dapat menimbulkan biaya yang cukup besar dan waktu yang cukup panjang);

4) yang diutamakan adalah segi-segi kepentingan, bukan hak-hak;

5) hubungan tetap terpelihara (berbeda dengan arbitrase yang menghasilkan situasi kalah-menang); dan

6) yang diusahakan adalah penyelesaian yang praktis dan konstruktif.

Mengenai uraian mediasi di atas, dapat ditarik prinsip-prinisp dasar yang melekat pada mediasi sebagai suatu lembaga penyelesaian sengketa, yaitu: ${ }^{20}$

\section{a. Parties Autonomy}

Para pihak sepakat secara sukarela untuk bermediasi dan diberikan kebebasan (freedom) dalam hal penentuan bentuk,

Namun dalam terdapat juga beberapa kritik terhadap alternatif penyelesaian sengketa, terutama mediasi, jika dibandingkan dengan litigasi pengadilan, yaitu (Emmy Yuhassarie (ed.), 2005, Op. cit., hlm. xxvii-xxix): (a) Mengancam hak-hak minoritas dalam hal community based mediation; (b) Sifat non-eksekusi membuat sulit bagi mediator memaksa para pihak melaksanakan putusan; (c) Hanya efektif dipatuhi jika hubungan para pihak sifatnya terus menerus atau terdapat tekanan masyarakat; (d) Mediasi tidak cocok untuk perkara yang menyangkut perkara pidana, bertujuan pembaharuan hukum, berdampak terhadap hak-hak sipil/konstitusi, dan yang memerlukan interpreatasi hukum; (e) Kualitas keadilan dipertanyakan jika terlalu mengesampingkan norma-norma hukum substantif dan prosedural dan sifat rahasia untuk kasuskasus yang mendapatkan perhatian publik; dan (f) Paradoks mediasi wajib seperti court-annexed mediation karena menghilangkan sifat dasar sukarela dari mediasi. 
proses, hasil keputusan, dan pelaksanaannya tanpa paksaan dari eksternal. ${ }^{21}$ Para pihak terlibat aktif dalam proses penyelesaian sengketa menuju hasil kesepakatan bersama. Para pihak dengan bantuan mediator dapat mendesain atau menyesuaikan sendiri prosedur bermediasi. Hal ini berbeda dengan prosedur litigasi yang terpaku pada hukum acara seperti pemanggilan saksi, pembuktian, replik, duplik, dan sebagainya. Dengan prosedur yang informal, para pihak yang terlibat dapat secara aktif mengontrol proses mediasi tanpa bergantung kepada pengacara atau mediator sekalipun. Disini peran mediator hanya memfasilitasi para pihak untuk mengeksplorasi kemungkinankemungkinan dalam menuju kesepakatan bersama. Mediator tidak dapat memaksakan untuk tercapainya kesepakatan.

b. Respect

Prosedur dalam mediasi sangat menghormati dan menjaga kepentingan masingmasing pihak yang terlibat. Dalam mediasi tidak ditentukan siapa yang benar atau salah, tetapi lebih menjaga kepentingan bersama para pihak yang berorientasi ke masa depan (interest based dan future looking). Komunikasi di antara para pihak dibantu oleh mediator dengan mengedepankan prinsip saling menghormati. Hal ini berbeda dengan litigasi atau arbitrase yang bersifat adversarial yang mempertentangkan posisi dan kepentingan para pihak layaknya peperangan yang sulit mempertemukan dua kepentingan yang berlawanan.

c. Efficiency

Fleksibilitas (para pihak menentukan sendiri desain prosedur mediasi) dan orientasi (interest based \& forward looking) yang ada dalam mediasi membuatnya menjadi suatu lembaga penyelesaian sengketa yang sederhana, cepat dan murah.

Dibandingkan dengan penyelesaian sengketa lainnya, mediasi menonjolkan kepentingan masing-masing pihak. Pengambil keputusan pada hakekatnya dilakukan oleh para pihak sendiri. Mediator hanya membantu prosesnya. Tata cara prosedural bersifat non-konfrontasi. Para pihak saling bekerja sama untuk mencapai kesepakatan. Fokus mediasi adalah menyelesaikan masalah dan memperhatikan kepentingan para pihak, yaitu apa yang diperlukan dan diinginkannya, dan yang merupakan kekuatirannya. Dengan proses dan prosedur mediasi seperti tersebut di atas, diharapkan didapatkan hasil penyelesaian yang adil yang dapat diterima oleh para pihak.

\section{Penerapan Teori Diskursus Habermas Dalam Mediasi}

a. Konsensus dalam Mediasi

Berdasar tindakan komunikatif Habermas, sebagaimana disebutkan di atas, para pihak mengkoordinasikan tindakan mereka untuk mencapai tujuan individu atau tujuan bersama yang didasarkan pada pemahaman bersama, dimana tujuan yang dicapai tersebut secara inheren masuk akal atau layak. Komunikasi para pihak akan berhasil mencapai kesepahaman bersama atau konsensus sepanjang memenuhi tiga klaim kesahihan, yaitu kebenaran (truth), ketepatan (normative rightness) dan kejujuran (sincerity). Klaim kesahihan ini dapat diterapkan dalam hal penyelesaian sengketa dalam bentuk negosiasi dan/atau mediasi. Artinya, negosiasi para pihak akan berhasil sepanjang dalam komunikasi mereka mengandung tiga klaim kesahihan,

21 Adanya mekanisme mediasi pengadilan (court-annexed mediation) yang bersifat wajib bagi para pihak yang bersengketa perkara perdata di pengadilan merupakan pengecualian dari prinsip sukarela atau party autonomy dari mediasi. 
dan sebaliknya negosiasi akan gagal jika dalam negosiasi tersebut misalnya diliputi oleh tindakan penipuan, ketidaklayakan dan/ atau ketidakjujuran.

Penyelesaian sengketa melalui mediasi dalam mencapai kesepakatan bersama mengandalkan komunikasi yang konstruktif di antara para pihak dengan dibantu oleh pihak ketiga netral, yang disebut dengan mediator. Mediasi sendiri merupakan suatu proses negosiasi yang dibantu oleh pihak ketiga. ${ }^{22}$ Mediasi memiliki karakteristik sukarela, dimana kesepakatan para pihak benar-benar merupakan kehendak para pihak dalam mediasi. Sementara berdasarkan teori diskursus Habermas, konsensus dianggap rasional jika para pihak dapat menyatakan pendapat dan sikapnya terhadap klaim-klaim kesahihan secara bebas dan tanpa paksaan.

Tugas mediator hanyalah memfasilitasi para pihak (tidak memberikan putusan atau penilaian) dalam mencapai kesepakatan bersama. Proses mediasi dan kesepakatan bersama yang diambil berorientasi pada kepentingan bersama dengan menjaga hubungan baik para pihak di masa mendatang. Mediasi akan berhasil apabila dalam negosiasi para pihak mengedepankan kepentingan bersama (interest based), tidak berdasarkan hanya mempertahankan posisinya (positional based).

Positional based adalah tipe negosiasi yang mengutamakan hasil akhir berupa menang atau kalah atau "win-lose negotiation." ${ }^{23}$ Ciri-ciri yang terdapat pada positional based dalam negosiasi adalah sebagai berikut: ${ }^{24}$

1) Nilai akhir kesepakatan yang menjadi tujuan;

2) Proses tawar-menawar menjadi ciri khas;

3) Keberhasilan ditentukan berdasarkan kedekatan antara nilai yang diinginkan dengan nilai akhir yang disepakati; dan

4) Adanya perasaan menang atau kalah.

Sementara pendekatan interest based memiliki karakteristik saling berbagi informasi tentang keinginan, kekhawatiran, dan posisi masing-masing, serta bersamasama memecahkan permasalahan untuk mencapai tujuan dan keinginan kedua belah pihak. $^{25}$ Dikotomi pendekatan positional based dan interest based serupa dengan pembedaan tindakan oleh Habermas, yaitu tindakan strategis (strategic action) dan tindakam komunikatif (communicative action). ${ }^{26}$ Pendekatan positional based dalam mediasi mendekati prinsip yang oleh Habermas disebut "tindakan strategis" karena keberhasilan ditentukan oleh terpenuhinya tujuan salah satu pihak secara sepihak. Sementara pendekatan interest based mendekati prinsip "tindakan komunikatif" Habermas, karena keberhasilan ditentukan oleh kesepakatan para pihak sepakat secara sukarela dengan mencapai tujuan bersama yang masuk akal.

Emmy Yuhassarie (ed.), 2005, op.cit, , hlm. 33.

Susanti Adi Nugroho, 2009, Mediasi Sebagai Alternatif Penyelesaian Sengketa, Edisi Pertama, Cetakan Ke-1, Telaga Ilmu Indonesia, Jakarta, hlm. 110.

Emmy Yuhassarie, 2005, Op. cit., hlm. 42.

Ibid.

Dalam tindakan komunikatif, para penutur mengkoordinasikan tindakan mereka untuk mencapai tujuan individu atau tujuan bersama yang didasarkan pada pemahaman bersama dimana tujuan yang dicapai tersebut secara inheren masuk akal atau layak. Sementara dalam tindakan strategis, keberhasilannya ditentukan apabila tujuan salah satu pihak atau secara sepihak tercapai. Dalam tindakan komunikatif, keberhasilan ditentukan jika para pihak sepakat secara sukarela dan tujuan-tujuan mereka adalah masuk akal sehingga pantas untuk suatu perilaku kerjasama. Sementara dalam tindakan strategis, para pihak memahami bahwa masing-masing berkomunikasi atau bernegosiasi untuk kepentingan sendiri. Dalam tindakan komunikatif, masing-masing pihak menyadari dan memahami bahwa komunikasi atau negosiasi diantara mereka dilakukan adalah untuk mencapai pemahaman bersama atau konsensus. Lihat Jürgen Habermas, Op. cit., hlm. 8-22. 
Hal lain yang harus diperhatikan bahwa proses mediasi harus betul-betul netral tanpa campur tangan dan tekanan dari pihak luar. Suatu konsensus akan menjadi lemah apabila terdapat intervensi keuangan dan kekuasaan, bukan komunikasi yang rasional. Oleh karena itu dalam mediasi, seorang mediator harus benar-benar dipastikan tidak memiliki konflik kepentingan dalam dirinya yang bersifat finansial, misalnya suap ataupun memiliki hubungan bisnis atau keuangan dengan salah satu pihak. Sedangkan intervensi dari pihak penguasa sangat rentan terjadi dalam mediasi yang bercorak publik, seperti kasus pertanahan dan perburuhan. Dalam mengimplementasikan teori Habermas, seorang mediator harus bersikap seobjektif mungkin, dimana salah satunya ia tidak boleh memiliki hubungan yang mengandung konflik kepentingan apapun dengan pihak yang bersengketa. Oleh karena itu, mediasi harus juga diperkuat dengan keberadaan kode etik atau standar perilaku bagi mediator untuk menjaga independensi dan kenetralannya dengan menghindari adanya benturan kepentingan dengan pihak yang bersengketa.

d. Tindak Komunikasi dan Diskursus dalam Mediasi

Menurut Habermas, orang harus membuat norma-norma yang mengatur perilaku mereka menjadi rasional. Tidak hanya dengan memberinya alasan-alasan rasional, melainkan juga melegitimasikannya secara intersubyektif. Proses untuk mencapai konsensus terlaksana dalam apa yang disebut "diskursus praktis". Dalam tipe diskursus ini para peserta mempersoalkan klaim ketepatan (rightness) dari norma-norma yang mengatur tindakan mereka.

Diskursus praktis (D) dapat kita nyatakan sebagai berikut: Suatu aturan, tindakan, atau pilihan dijustifikasi, dan oleh karenanya sahih, hanya jika semua yang terkena aturan atau pilihan tersebut dapat menerimanya dalam diskursus yang rasional. Etika diskursus Habermas sangat tergantung pada kapasitas individu untuk suatu dialog moral. Meskipun secara faktual tidak semua orang yang bersangkutan bisa hadir dalam diskursus praktis, para peserta diskursus yang ada harus berusaha keras untuk menemukan konsensus yang seluas mungkin atas norma tersebut. Di dalam prinsip etika diskursus itu tersembunyi sebuah prinsip lain yang disebut Habermas sebagai "prinsip universalisasi" ("U"). Prinsip terakhir ini tak lain daripada aturan argumentasi itu sendiri. Bunyinya adalah sebagai berikut: setiap norma yang sahih harus memenuhi prasyarat bahwa efek dan efek samping yang mungkin terjadi karena kepatuhan umum untuk pemenuhan kepentingan setiap individu dapat diterima tanpa paksaan oleh semua orang yang bersangkutan dengan norma itu.

Universalitas (U) adalah prinsip diskursus nyata. Penilaian moral seseorang dianggap sepenuhnya rasional hanya jika dilakukan dengan partisipasi dalam diskursus aktual oleh semua orang yang terkena dampak. Lebih dari itu, (U) mensyaratkan tidak hanya bahwa seseorang mencari masukan dari orang lain dalam membentuk kesadaran seseorang, tetapi seseorang memperoleh kesepakatan yang rasional. Diskursus tidak selalu dapat melibatkan semua pihak yang terkena dampak. Yang mungkin dapat dicapai adalah justifikasi parsial, yaitu argumentasi yang tidak terlalu meyakinkan untuk semua, tetapi juga tidak dapat dikatakan argumentasi tersebut terbantahkan sehingga masih dianggap sebagai argumentasi yang rasional. ${ }^{27}$

Mediasi mengandaikan adanya komu- 
nikasi yang konstruktif untuk mencapai kesepakatan bersama. Dengan demikian, tindakan komunikasi antar pihak dalam mediasi sangatlah penting. Meminjam pendekatan tindakan komunikatif Habermas, satu pihak mengungkapkan permasalahan dan tuntutannya. Pihak yang lain juga dapat memproblematisasi permasalahan yang diajukan oleh salah satu pihak, serta juga dapat mengajukan tuntutan pembanding (counter claim). Di sinilah pentingnya peran mediator untuk dapat mengevaluasi setiap pernyataan yang diajukan oleh para pihak, memvalidasinya guna mencapai kesepakatan bersama.

Habermas membagi tiga bentuk argumentasi, yaitu argumentasi sebagai produk, argumentasi sebagai prosedur, dan argumentasi sebagai proses, atau ketiganya bisa diseleraskan sebagai: 1) logika; 2) dialetika; dan 3) retorika. Pada tingkat logika, para pihak menganggap argumentasi sebagai produk, yaitu sejumlah alasan yang mendukung kesimpulan. Dari perspektif ini, pihak yang berargumentasi bertujuan membangun "argumen yang meyakinkan" dari sifat intrinsik argumentasi dan dengan mana klaim kesahihan dapat ditentukan. Kekuatan logis dari argumentasi semacam itu tergantung pada seberapa baik seseorang telah mempertimbangkan semua informasi yang relevan untuk menghindari kemungkinan terjadinya keberatan dari pihak lawan. Penilaian logis mengandaikan adanya kecukupan dialektis dari prosedur argumentatif. Produk dari praktik pembuatan argumen adalah kuat secara logis hanya jika pada tingkat dialektika, telah diberikan argumentasi dan kontra argumentasi dalam suatu diskusi kritis yang keras. ${ }^{28}$
Habermas mengatakan kondisi ini sebagai "kompetisi ritual untuk argumen yang lebih baik." Para peserta dalam dialektika harus dapat mengemukakan masalah yang dihadapi, menanggapi keberatan yang relevan, memenuhi beban pembuktian yang diajukan, dan sebagainya. Oleh karenanya, dalam proses mediasi, mediator harus membangun komunikasi dialogis antara para pihak, memberikan kesempatan yang sama kepada para pihak untuk mengemukakan permasalahan dan tuntutannya, serta mendengarkan keduabelah pihak secara seimbang. Jika diperlukan, mediator dapat mengklarifikasi pernyataan salah satu pihak atau meminta bukti pendukung dari pernyataan tersebut.

Pengujian kritis terhadap pernyataan para pihak pada gilirannya bergantung pada kualitas retorika proses persuasif. Perspektif retorika dimaksudkan untuk mendesain argumentasi untuk menempatkan audiens dalam ruang sosial-psikologis yang tepat untuk membuat penilaian kolektif yang bertanggung jawab. Aspek retorika cocok diterapkan pada mediasi yang bersifat terbuka seperti mediasi publik. Dalam mediasi publik, pihak yang berkepentingan dapat hadir, walaupun tidak harus menjadi pihak penutur. Para pihak yang terlibat langsung mediasi seperti ini bukan hanya harus dapat meyakinkan pihak lawannya, tetapi juga dapat meyakinkan para audiens yang hadir, yang juga merupakah pihak yang berkepentingan.

Suatu dialektika dapat dikatakan telah terlaksana memenuhi pengujian kritis jika memenuhi prasyarat pragmatis, yaitu: ${ }^{29}$

1) tidak ada pihak yang mampu memberikan kontribusi yang relevan dikecualikan;

2) peserta memiliki suara yang

Jürgen Habermas, Op. cit., hlm. 26

Jürgen Habermas, 2005, Truth and Justification, The MIT Press, Massachusetts, hlm. 106-107. 
sama;

3) para pihak bebas untuk mengemukakan pendapat jujur tanpa penipuan atau penipuan diri; dan

4) tidak ada sumber tekanan yang melekat pada proses dan prosedur diskursus.

Prasyarat ini pada dasarnya mengharuskan semua pihak untuk menilai semua informasi dan argumen yang relevan serasional mungkin, dan mempertimbangkan argumentasi hanya didasarkan pada kepantasan dalam pencapaian kebenaran yang tidak memihak. Salah satu tantangan untuk menjalankan teori Habermas pada mediasi adalah persyaratan pelibatan semua pihak yang terdampak untuk berpartisipasi sehingga diskursus bersifat inklusif.

Kenyataannya, adalah tidak mungkin semua pihak yang terdampak dapat berpartispasi dalam suatu proses mediasi, terutama dalam mediasi publik, seperti dalam kasus agraria atau pertanahan. Oleh karena itu, jalan keluarnya adalah dengan hanya melibatkan perwakilan dari pihak-pihak yang bersengketa. Namun, pihak representatif memposisikan diri sebagai semua pihak yang terkena dampak, dan keputusan harus diambil dengan mempertimbangan semua pihak yang terkena dampak meskipun mereka tidak berpartisipasi dalam diskusi.

Selama proses mediasi, mediator harus memastikan bahwa setiap pihak dapat mempermasalahkan setiap pernyataan, memperkenalkan isu baru, dan mengungkapkan keinginan maupun keyakinannya sendiri. Untuk memenuhi hal tersebut, mediator harus memperingatkan para pihak bahwa mereka memiliki hak untuk didengar selama mediasi dengan tujuan mendorong agar mereka mengungkapkan pernyataan dan pertanyaan. Selama proses mediasi, mediator secara berkala harus menanyakan apakah para pihak memiliki pertanyaan dan apakah para pihak setuju atau tidak setuju pada setiap pernyataan pihak lawan.

Teknik komunikasi merupakan salah satu keahlian penting yang harus dimiliki oleh mediator. Sebagian besar peran mediator dalam proses mediasi adalah bertanya dan mendengar. ${ }^{30}$ Dalam hal ini, mediator menggunakan teknik mendengar aktif. Mediator banyak mendengar untuk mengetahui kepentingan para pihak, melihat permasalahan secara lebih jernih, dan mencari akar permasalahan. Teknik mendengar aktif yang digunakan oleh mediator adalah sebagai berikut: $^{31}$

1) Attending skill: mediator berdekatan dengan pihak yang bersengketa, mendengarkan, dan bertatapan;

2) Following skill: mediator mendengarkan para pihak dan kemudian mengajukan pertanyaan. Ketika seseorang bercerita, mediator memancing pihak tersebut untuk terus bercerita dengan terus mengajukan pertanyaan; dan

3) Reflecting skill: apa yang telah diceritakan para pihak, mediator kemudian merangkum dan menyampaikan kembali kepada para pihak. Tujuannya agar para pihak merasa bahwa apa yang disampaikannya itu benar-benar didengar oleh si mediator.

Berdasar teknik mendengar aktif, terlihat bahwa komunikasi memainkan peranan yang penting dalam proses mediasi untuk mencapai kesepakatan bersama. 
Disamping teknik mendengar-aktif, mediator juga harus memiliki kemampuan untuk mengajukan pertanyaan yang terdiri dari beberapa teknik sebagaimana dalam tabel berikut:

Tabel 1.

Teknik Bertanya dalam Mediasi

\begin{tabular}{|c|c|c|}
\hline Tipe & Tujuan & Contoh \\
\hline Open Question & $\begin{array}{l}\text { Umum, efektif untuk } \\
\text { penukaran informasi }\end{array}$ & $\begin{array}{l}\text { "Budi, bisakah anda menjelaskan apa dampak } \\
\text { kecelakaan ini bagi anda?" }\end{array}$ \\
\hline Closed Question & $\begin{array}{l}\text { Memperoleh jawaban "ya" } \\
\text { atau "tidak", lebih spesifik }\end{array}$ & $\begin{array}{l}\text { "Agus, apakah kecelakaan ini disebabkan oleh sistem } \\
\text { produksi yang diterapkan pada pabrik ini?" }\end{array}$ \\
\hline $\begin{array}{l}\text { Clarifying } \\
\text { Question }\end{array}$ & Memeriksa tingkat kebenaran & $\begin{array}{l}\text { "Budi, apakah benar bahwa perawatan rutin terhadap } \\
\text { mesin tersebut telah dilakukan beberapa saat sebelum } \\
\text { kecelakaan ini terjadi?" }\end{array}$ \\
\hline $\begin{array}{l}\text { Reflective } \\
\text { Question }\end{array}$ & Merefleksikan suatu kondisi & $\begin{array}{l}\text { "Budi, jadi saat ini anda merasa bahwa anda berada } \\
\text { pada posisi yang lemah?" }\end{array}$ \\
\hline $\begin{array}{l}\text { Hypothetical } \\
\text { Question }\end{array}$ & $\begin{array}{l}\text { Mempertimbangkan opsi } \\
\text { tanpa perlu melakukan } \\
\text { komitmen dulu }\end{array}$ & $\begin{array}{l}\text { "Budi, apabila masalah kompensasi dapat disepakati, } \\
\text { bagaimana pendapat anda tentang pelatihan kese- } \\
\text { lamatan kerja bagi karyawan di pabrik ini?" }\end{array}$ \\
\hline $\begin{array}{l}\text { Undirected } \\
\text { Question }\end{array}$ & $\begin{array}{l}\text { Pertanyaan yang dapat } \\
\text { dijawab oleh salah satu pihak }\end{array}$ & $\begin{array}{l}\text { "Langkah-langkah apakah perlu dilakukan agar } \\
\text { kejadian ini tidak terulang kembali?" }\end{array}$ \\
\hline Probing Question & $\begin{array}{l}\text { Memperoleh justifikasi dan } \\
\text { konfirmasi }\end{array}$ & $\begin{array}{l}\text { "Budi, apabila anda mengikuti pelatihan ulang, } \\
\text { bisakah anda bekerja dengan peralatan yang } \\
\text { berteknologi mutakhir, yang mana sebelumnya hal } \\
\text { tersebut merupakan tantangan tersendiri bagi anda?" }\end{array}$ \\
\hline
\end{tabular}

Sumber: Emmy Yuhassarie, 2005 32

Mediator, selain itu, juga harus memiliki kemampuan membingkai ulang pernyataan (reframing). Reframing menurut Slaikeu, sebagaimana dikutip oleh Faisal, merupakan suatu teknik komunikasi yang mengubah bahasa yang satu ke bahasa yang lain, dengan tujuan agar lebih cocok untuk pihak lain dan memberikan situasi yang kondusif bagi penyelesaian permasalahan di antara para pihak secara kolaboratif. ${ }^{33}$

Mediator selanjutnya harus memperhatikan jika para pihak merasa tidak nyaman untuk mengungkapkan pemikirannya. Dalam kasus ini, mediator harus mengklarifikasi penyebabnya dan meyakinkan para pihak bahwa mereka berada dalam area yang aman. Mediator harus memperhatikan, apakah satu pihak masih berkeinginan untuk diyakini oleh argumentasi pihak lain atau apakah mediasi terancam menemui jalan buntu. Jika terjadi kebuntuan, mediator harus mencari strategi untuk dapat memotivasi para pihak untuk menggunakan rasio komunikatif ketimbang rasio instrumental. Salah satu cara untuk menciptakan rasio komunikatif diantara para pihak dimungkinkan bagi mediator untuk mengadakan pertemuan terpisah (separate meeting) antara mediator dengan salah satu pihak secara bergantian. Tujuan pertemuan terpisah dalam mediasi 
sebagaimana diungkapkan oleh Said Faisal adalah sebagai berikut: ${ }^{34}$

1) menggali permasalahan yang belum terungkap dan dianggap penting guna tercapainya kesepakatan;

2) memberikan suasana dinamis pada proses negosiasi bilamana ditemui jalan buntu;

3) menjalankan 'tes realitas' terhadap para pihak;

4) menghindarkan kecenderungan mempertahankan pendapat para pihak pada sesi pertemuan bersama;

5) mengingatkan kembali atas halhal yang telah dicapai dalam proses ini; dan

6) mempertimbangkan akibat bila tidak tercapai kesepakatan.

Tujuan dari pertemuan terpisah dalam mediasi mendukung prinsip tindakan komunikatif Habermas yang mensyaratkan rasionalitas para pihak dalam diskursus. Sangat dimungkinkan dalam proses mediasi, salah satu pihak berkomunikasi secara tidak rasional, memberi pernyataan yang tidak valid, dan menggunakan cara tindakan strategis (hanya mementingkan diri sendiri) sehingga mengancam kelancaran proses mediasi. Dalam situasi seperti ini, mediator dapat segera menetralisir pihak-pihak yang irasional dalam berkomunikasi dengan mengadakan pertemuan terpisah. Hal lain yang harus diperhatikan untuk menciptakan situasi ketidakberpihakan, mediator harus memberikan kesempatan yang sama dan waktu yang (relatif) sama kepada para pihak ketika diadakan pertemuan terpisah dengan mediator.
3. Klaim Kesahihan dalam Mediasi

Setiap pernyataan dalam komunikasi harus mengandung klaim kesahihan (validity claim) untuk mencapai suatu konsensus. Klaim kesahihan suatu pernyataan pada dasarnya adalah ketika kita tahu apa yang membuat pernyataan dapat diterima. Berdasarkan prinsip klaim kesahihan, Habermas mengaitkan makna tindak tutur dengan praktik pemberian alasan, dimana tindak tutur secara inheren melibatkan klaim yang membutuhkan alasan, klaim yang mana terbuka untuk kritisi dan justifikasi. Suatu tindak tutur berhasil mencapai suatu pemahaman ketika pendengar mengambil "posisi afirmatif" terhadap klaim yang dibuat oleh penutur. ${ }^{35}$

Tindakan komunikatif mengutamakan aturan pemahaman bersama (common understanding) dengan menghindari kalkulasi egoistik. Selama diskursus, individu berusaha untuk meyakinkan pihak lawan bicara untuk merubah argumentasinya dengan tujuan untuk mencapai konsesus yang rasional. ${ }^{36}$ Diskursus adalah rasional sepanjang memenuhi tiga klaim validitas, yaitu: ${ }^{37}$

1) Kebenaran (truth), yaitu argumentasi mengimplikasikan klaim kebenaran dan memiliki tujuan komunikasi sesuatu tentang realitas yang diobjektivikasi;

2) Ketepatan (normative rightness), yaitu norma-norma dasar dari diskursus harus dapat diterima secara moral; dan

3 Goldkuhl G., "The Validity of Validity Claims: An Inquiry Into Communication Rationality", dalam Mareike Schoop dan Christoph Quix (ed), 2000, Proceedings Of The Fifth International Workshop On The Language-Action Perspective on Communication Modelling, LAP, Aachen, hlm. 173.

37 Ibid. Di samping ketiga klaim kesahihan tersebut, Habermas juga membericarakan klaim komprehensibilitas. Namun menurut Goldkuhl (ibid), klaim komprehensibilitas merupakan dasar untuk tiga klaim lainnya. 
3) Kejujuran/ketulusuan (sincerity), yaitu pembicara harus jujur dan sesuai dengan apa yang dikatakan. Setiap individu yang mampu dan berkeinginan untuk memenuhi klaim kesahihan ini dalam sebuah diskursus mengartikan bahwa ia telah bertindak secara rasional.

Habermas dengan memperhatikan kompleksitas interaksi sosial, menentukan hubungan dari ketiga klaim kesahihan dasar dalam setiap tindak tutur yang digunakan bagi terciptanya tujuan kerja sama. Terdapat tiga hubungan dunia (world relations) yang terdapat dalam tindakan komunikatif dimana penutur bermaksud mengatakan sesuatu kepada seseorang tentang sesuatu. ${ }^{38}$ Misalnya, tindak tutur konstatif (pernyataan fakta): 1) mengekspresikan dunia batin (niat untuk mengkomunikasikan keyakinan); 2) membangun hubungan komunikatif dengan pendengar (dan dengan demikian berhubungan dengan dunia sosial, khususnya di mana kedua orang berbagi sebuah informasi, dan tahu mereka melakukannya); dan 3) berupaya mewakili dunia eksternal.

Orang dalam masyarakat moderen tak dapat menerima begitu saja norma-norma yang mengatur perilaku mereka. Jika sistemsistem kepastian tradisional mengalami krisis dan segalanya dapat dipersoalkan, menurut Habermas, orang harus membuat norma-norma yang mengatur perilaku mereka menjadi rasional, tidak hanya dengan memberinya alasan-alasan rasional, melainkan juga melegitimasikannya secara intersubyektif. ${ }^{39}$ Dengan kata lain, orang harus mencapai konsensus rasional atas norma-norma tersebut. Dalam masyarakat moderen yang kompleks, konsensus yang kuat sulit terjadi karena masyarakat ini tidak didasarkan pada nilai dan norma budaya yang sama, sehingga dalam situasi ini konsensus diperlonggar. Diperlonggar artinya tidak semua tiga klaim kesahihan tersebut hadir dalam suatu argumentasi.

Ketika salah satu pihak tidak dapat menerima suatu pernyataan pihak lain sebagai klaim validitas atau kesahihan, para pihak dapat merubah tingkatan refleksifnya, dari perbincangan biasa ke "diskursus", yaitu proses argumentasi dan dialog dimana klaim yang tersirat dalam tindak tutur diuji untuk dijustifikasi secara rasional sebagai benar (true), tepat (right), atau otentik (authentic). Mediator juga harus meminta keinginan para pihak untuk mencapai persetujuan untuk menyelesaikan sengketa dengan cara, misalnya, meminta mereka untuk menjelaskan mengapa suatu pernyataan adalah relevan, dengan tujuan untuk menghindari diskusi tidak produktif yang membuang waktu atau untuk membuka pihak lain. ${ }^{40}$ Jika pernyataan satu pihak tidak benar, mediator dengan strategi membantu menunjukan inkoherensi pernyataan tersebut dengan cara mengklarifikasinya. Yang penting dalam melakukan klarifikasi, mediator tidak boleh dan dipersepsikan menunjukan keberpihakan kepada salah satu pihak dengan menyerang pernyataan satu pihak secara terbuka sebagai pernyataan tidak benar, tepat, atau jujur. Melainkan sebagaimana telah dijelaskan, mediator dapat menggunakan teknik mendengar-aktif, bertanya, dan membingkai ulang pernyataan (reframing).

Jürgen Habermas, 1984, Op. cit., hlm. 275.

Budi Hardiman, "Etika Politik Habermas", Makalah Seri Kuliah Umum, November, 2010, hlm. 5.

Stephen Chilton dan Maria Stalzer Wyant Cuzzo, "Habermas's Theory of Communicative Action as a Theoretical Framework for Mediation Practice", Conflict Resolution Quarterly, Volume 22, Nomor 3, 2005, hlm. 329. 
Pembicara dalam tindakan komunikatif Habermas melakukan tindak tutur yang berorientasi pada saling pengertian dengan mengajukan klaim kesahihan, dan mengandaikan bahwa klaim kesahihan akan diterima oleh pendengar. Komunikasi yang baik mensyaratkan pendengar memahami dan menerima tindak tutur. Pendengar menyetujui atau mengafirmasi penyataan pembicara. Jika tindak tutur diterima, timbulah yang dinamakan hubungan pelaku (actor relationship) yang meciptakan hubungan sosial.

Menurut Habermas, dunia dapat dibagi menjadi tiga. ${ }^{41}$ Pertama, dunia subyektif (bagian dunia internal) yang didasari oleh perasaan, kepercayaan, keinginan, pengalaman, dan niat para pelaku. Kedua, dunia sosial bersama yang dibentuk oleh norma, hubungan aktor, lembagalembaga, dan kemana para aktor pelaku itu menempatkan dirinya (bagian dari dunia luar). Ketiga, dunia objektif yaitu objek dan keadaan yang objektif (bagian dari dunia luar). Habermas berpendapat bahwa seorang pembicara yang melakukan tindakan bicara pada saat yang sama harus menciptakan klaim validitas kebenaran, ketulusan, dan pemahaman oleh pendengar tindak tutur ingin berhasil. ${ }^{42}$

Pembicara melakukan tindak tutur yang diungkapkan dalam pesan atau pernyataan. ${ }^{43}$ Pembicara memiliki tujuan menciptakan hubungan pelaku (actor relationship) dengan pendengar. Ketika tindak tutur dilakukan, akan ada kaitannya dengan salah satu tiga dunia yang telah diungkapkan sebelumnya. Hubungan dunia 1 (subjektif) ditekankan dengan asertif, hubungan dunia 2 (sosial) dengan ekspresif, hubungan dunia 3 (objektif) dengan regulator. Jika tindak tutur berhasil, pendengar harus memahami dan menerima tindak tutur tersebut. Pendengar harus terlebih dahulu memahami tindak tutur dan juga harus menerima tindak tutur sebagai sah. Pendengar sepenuhnya memahami tindakan bicara ketika dia tahu dalam kondisi apa tindakan bicara itu bisa diterima. Mengetahui kondisi ini menyiratkan bahwa pendengar diberi kesempatan untuk mengendalikan dengan mengkritik atau memberi respons terhadap tindak tutur pembicara berdasarkan tiga klaim kesahihan, yaitu kebenaran, ketepatan, dan kejujuran. Pendengar akan menerima tindak tutur pembicara jika pembicara dapat memberikan alasan yang baik.

Implementasi dalam mediasi adalah ilustrasi sebagai berikut. Terjadi sengketa perebutan anak antara seorang ibu (menantu) dengan mantan ibu mertua yang merasa sang cucu seharusnya dirawat oleh kakekneneknya ketimbang sang ibu yang kurang secara keuangan. Ibu mertua mengatakan, "demi kebaikan ' $X$ ', serahkan pengasuhannya kepada saya". Jika sang menantu memahami dan menyetujuinya, berarti dia memahami pernyataan sang mertua sebagai hal yang benar, tepat, dan tulus. Dengan demikian, timbulah saling kesepahaman yang berujung pada terciptanya hubungan antara si ibu dan mantan ibu mertua terkait dengan pengasuhan " $X$ ".

Sang ibu, meskipun demikian, bisa melakukan kontestasi kesahihan pernyataan sang ibu mertua dengan menyangsikan kebenaran, ketepatan atau ketulusannya. Kemungkinan respons sang ibu adalah

\footnotetext{
41 Owen Eriksson, "A Generic Communication Model based on Habermas and Searles versions of Speech Act Theory", dalam G. Goldkuhl, et. al., (ed), 1999, Proceedings of the fourth International Workshop on the Language Action Perspective on Communication Modelling, Language Action Perspective, Copenhagen, hlm. 45.$$
42 \text { Ibid. }
$$

43 Ibid., hlm. 46.
} 
sebagai berikut:

a. Klaim kebenaran (truth):

"Tidak, selama ini anak saya 'X' baik-baik saja";

b. Klaim ketepatan (rightness): "Tidak, hal tersebut merupakan upaya anda untuk mempermalukan saya di depan orang lain karena seorang anak seharusnya dirawat oleh ibu kandungnya"; dan

c. Klaim kejujuran (sincere): "Tidak, hal tersebut sebenarnya hanya upaya balas dendam anda karena sakit hati anak anda pernah saya gugat cerai”.

Apa yang harus dilakukan oleh mantan ibu mertua adalah memberikan jawaban balasan dengan alasan yang masuk akal sehingga dapat diterima oleh si menantu. Di sinilah kemudian tercipta dialogis antara mantan menantu dan ibu mertua. Sang mantan ibu mertua harus dapat meyakinkan si menantu bahwa pernyatannya adalah benar, tepat, dan jujur. Mediator dapat mengambil peran di sini dengan membantu mengklarifikasi lewat mengajukan pertanyaan ulang kepada kedua belah pihak sehingga tercipta suasana dialogis. Susana dialogis ini dapat berujung pada dua kemungkinan. Pertama, pada akhirnya sang mantan menantu dapat memahami dan menyetujui pernyataan mantan ibu mertua sebagai hal yang benar, tepat, dan tulus sehingga tercipta saling kesepahaman di antara mereka dalam pengurusan si anak "X". Kedua, dalam dialog terungkap misalnya ketidaktulusan sang ibu mertua bahwa ternyata ia pernah sakit hati anaknya diceraikan oleh sang menantu sehingga dapat mengancam terjadinya kebuntuan dalam mediasi.

Untuk menguji keraguan atas klaim kebenaran, mediator bisa melakukan klarifikasi kepada keduabelah pihak dengan mendorong mereka untuk saling meyakinkan, jika perlu dengan menghadirikan bukti yang dipegang masing-masing. Bukti di sini misalnya bisa didapat dari catatan kesehatan rumah sakit, rapor, laporan dari guru, laporan dari tetangga, dan sebagainya. Jika ternyata si anak "X" kondisi kesehatannya baik-baik saja, prestasi di sekolah tidak memburuk, dan tidak ada permasalahan dengan lingkungan sosial, maka pernyataan ibu mertua tidak mengandung kebenaran. Pada titik ini, saling kesepahaman kemungkinan besar tidak terjadi. Namun jika memang kondisi kesehatan si anak " $\mathrm{X}$ " dapat diobservasi bermasalah, prestasi di sekolah menurun, terdapat laporan dari guru dan tetangga tentang kenakalan si $\mathrm{x}$, maka pernyataan ibu mertua adalah valid atau sahih. Tugas mediator adalah mengkoreksi keraguan si menantu bahwa secara objektif kondisi anak "X" memang ada permasalahan sehingga diperlukan langkah-langkah perbaikan yang segera dan dapat dilaksanakan.

Mediator dapat memberikan pemahaman kepada keduabelah pihak untuk mengatasi klaim kebenaranan bahwa yang terpenting di sini adalah kesejahteraan anak seperti gizi yang cukup, kesehatan yang terjamin, serta pendidikan yang baik. Opsi yang dapat diberikan dalam situasi di atas adalah bersifat sementara. Dalam arti, selama si menantu belum dapat memperbaiki kehidupan ekonominya, si anak " $X$ " diasuh terlebih dahulu dengan kakek-neneknya. Artinya, kalau si menantu bisa membuktikan kondisi sosial perekonomiannya cukup, diindikasikan dengan misalnya gaji yang memadai, atau rumah yang memadai, yang mana keduanya bisa dihasilkan baik dari karirnya sendiri atau menikahi lelaki yang cukup mapan. Namun sebaliknya, jika nantinya bersuami dengan lelaki yang mapan, sang menantu harus dapat membuktikan 
kepada mertua bahwa sang suami tetap sayang kepada " $\mathrm{X}$ " walaupun bukan anak kandung. Dengan demikian peran mediator di sini adalah menghindari kebenaran tunggal dengan menambah atribut klaim kebenaran yang dapat diterima keduabelah pihak.

Untuk menguji keraguan atas klaim ketepatan, mediator bisa melakukan menggunakan pandangan ahli (expert) atau secara persuasif menggunakan pandangannya sendiri jika ia memang ahli di bidang psikologi anak misalnya, agar para pihak dapat saling memahami. Kalau norma sosial menyatakan bahwa seorang anak harus dirawat oleh ibu kandung maka keinginan si ibu mertua untuk merawat " $X$ " adalah tidak tepat. Namun jika norma sosial yang berkembang menyatakan si anak memiliki hak atas kesejahteraan hidup, maka pernyataan ibu mertua dapat diterima oleh masyarakat. Dimungkinkan kedua norma tersebut dapat dibenarkan oleh masyarakat, untuk mengatasi klaim ketepatan ini, mediator harus dapat meyakinkan keduabelah pihak, terutama kepada menantu bahwa apa yang dilakukan oleh mertua adalah semata demi kebaikan si "X" dengan tidak ada maksud untuk mempermalukan si menantu sebagai orang tua "X". Opsi yang dapat diberikan misalnya, si ibu tetap dapat mengunjungi si anak "X" tanpa halangan. Atau, pada setiap akhir pekan " $\mathrm{X}$ " diasuh di rumah ibunya untuk memperlihatkan kepada orang lain bahwa si ibu juga tetap berperan dalam mengasuh "X". Hal yang dapat ditambahkan pada kesepakatan bahwa mereka tidak akan memperbesar permasalahan dan menyebar rumor yang menyudutkan salah satu pihak dimana urusan ini hanya keduabelah pihak yang boleh mengetahuinya. Dengan demikian peran mediator di sini adalah menghadirkan pandangan yang objektif untuk mengatasi keraguan terhadap klaim ketepatan sehingga hubungan yang tercipta secara sosial dapat diterima.

Untuk menguji keraguan atas klaim kejujuran, mediator bisa melakukan klarifikasi pengalaman-pengalaman yang terjadi di antara keduabelah pihak dalam hubungannya sebagai menantu-mertua sebelum perceraian maupun sesudah perceraian. Jika dari awal misalnya terungkap bahwa sebenarnya ibu mertua tidak menyetujui pernikahan si menantu dengan anaknya, selama pernikahan mereka ibu mertua selalu menyalahkan si menantu sehingga timbul kecekcokan, dan peristiwa-peristiwa lain yang menunjukan ketidaksukaan subjektif ibu mertua, maka keinginan ibu mertua untuk merawat " $\mathrm{X}$ " adalah tidak jujur. Namun mungkin saja ketidaksukaan ibu mertua adalah objektif, misalnya si menantu memang tidak becus merawat anak dan melayani suami. Dalam situasi seperti ini, yang lebih penting bukan mencari solusi terhadap klaim kejujuran melainkan klaim kebenaran dan ketetapan sebagaimana diuraikan di atas. Mediator harus dapat meyakinkan kepada kedua belah pihak, terutama kepada si menantu, bahwa tidak ada maksud tersembunyi selain untuk kepentingan dan kebaikan "X". Ketulusan sang ibu mertua bahwa hal ini semata demi kepentingan dan kebaikan " $\mathrm{X}$ " dapat dilihat, sebagaimana dalam opsi yang dijelaskan di atas. Ketika ia menyetujui dalam kesepakatan bahwa jika si menantu sudah mapan, pengasuhan diberikan sepenuhnya kepada menantu, dan selama dalam pengasuhan mertua, si anak " $\mathrm{X}$ " boleh dikunjungi oleh ibunya dan/atau menginap di akhir pekan bersama ibunya.

Seandainya pun terungkap sakit hati mertua kepada menantu karena anaknya diceraikan yang mana hal ini dapat berujung pada ketidaksepahaman di antara para pihak, mediasi memiliki keunggulan untuk mengatasi situasi seperti ini. Mediator, misal dalam pertemuan terpisah terutama kepada 
ibu mertua, meyakinkan bahwa tindakan tersebut tidak tepat karena yang dikorbankan nantinya adalah kepentingan anak "X". Mediator juga harus dapat meyakinkan keduabelah pihak bahwa jangan melihat mundur kebelakang (backward looking) melainkan kepentingan bersama ke depan (forward looking). Kepentingan bersama kedepan di sini adalah kesejahteraan atau kebaikan si anak "X". Apabila masih terbersit sakit hati atau dendam, pada forum mediasi inilah para pihak dapat saling menerima dan memaafkan demi kepentingan yang lebih baik. Dengan demikian komunikasi mediator untuk mengatasi keraguan klaim ketulusan adalah bersifat retorika.

Tabel 2.

Penerapan Klaim Kesahihan Habermas dalam Teknik Mediasi

\begin{tabular}{llll}
\hline \multicolumn{1}{c}{ Klaim Kesahihan } & \multicolumn{1}{c}{ Distorsi } & \multicolumn{1}{c}{ Alat Intervensi } & \multicolumn{1}{c}{ Teknik Mediasi } \\
\hline Kebenaran (truth) & Subjektivitas & Bukti (evidence) & Klarifikasi \\
\hline Ketepatan (rightness) & Pertentangan norma dan nilai & Pendapat Ahli & Persuasi \\
\hline Ketulusan (sincerity) & Pengalaman buruk & Retorika & Persuasi dan Reframing \\
\hline
\end{tabular}

Sumber: Diolah oleh penulis, 2019

\section{Penutup}

Teori dikursus Habermas memiliki kesamaan dengan konsep mediasi yang menggunakan pendekatan interest based, di mana keduanya bertujuan untuk mencapai konsensus atau kesepahaman bersama dari para pihak yang berargumentasi atau bersengketa. Konsensus atau kesepahaman bersama ditempuh melalui bantuan pihak ketiga netral, dalam hal ini mediator, yang bertugas menciptakan suatu komunikasi yang rasional dengan melibatkan sebanyak-banyaknya pihak peserta terkait dan memvalidasi setiap pertanyataan masing-masing pihak sebagai suatu pernyataan yang benar, tepat, dan tulus agar dapat diterima oleh para pihak sehingga terciptanya suatu konsensus diantara mereka yang bersengketa.

Teori klaim kesahihan Habermas dalam penerapan sehari-hari dapat membantu mediator untuk: 1)memprediksiakan terciptanyakesepakatan, atau seandainyapun kesepakatan tercipta apakah ia akan berlangsung lama; 2) mengidentifikasi pernyataan-pernyataan yang diragukan kebenaran, ketepatan, ketulusannya, dan membantu para pihak mengklarifikasinya; dan 3) membantu timbulnya opsi-opsi kesepakatan dengan tujuan menciptakan kesepahaman bersama untuk bekerjasama.

\section{DAFTAR PUSTAKA}

\section{A. Buku}

Friedman, Lawrence M., 2009, Sistem Hukum Perspektif Ilmu Sosial, (A Legal System a Social Science Perspective), diterjemahkan oleh M. Khozim, Nusa Media, Bandung.

Habermas, Jürgen, 1984, Theory of Communicative Action, Volume One: Reason and the Rationalization of Society, diterjemahkan oleh Thomas A. McCarthy, Boston, Massachuset, Beacon Press.

, Jürgen, 2005, Truth and Justification, The
MIT Press, Massachusetts.

Hardiman, Budi, 2009, Kritik Ideologi, Penerbit Kanisius, Yogyakarta.

Budi, 2009, Menuju Masyarakat Komunikatif, Penerbit Kanisius, Yogyakarta.

H.S., Salim dan Nurbani, Erlies Septiana, 2013, Penerapan Teori Hukum pada Penelitian Tesis dan Disertasi, Raja Grafindo, Jakarta.

Jay, Martin, 2009, Sejarah Mazhab Frankfurt, Imajinasi Dialektis dalam Perkembangan Teori Kritis, diterjemahkan oleh Nurhadi, 
Kreasi Wacana, Yogyakarta.

Merrills, John G., 1991, International Dispute

Settlement, Penterjemah Achmad Fausan,

Penyelesaian Sengketa Internasional,

Tarsito, Bandung.

Nugroho, Susanti Adi, 2009, Mediasi Sebagai Alternatif Penyelesaian Sengketa, Edisi Pertama, Cetakan Ke-1, Telaga Ilmu Indonesia, Jakarta.

Suseno, Franz Magnis, 2005, Pijar-Pijar Filsafat. Penerbit Kanisius, Yogyakarta.

Yuhassarie, Emmy (ed.), 2003, Arbitrase dan Mediasi, Pusat Pengkajian Hukum, Jakarta. , Emmy, (ed.), 2005, Mediasi dan Court Annexed Mediation, Pusat Pengkajian Hukum, Jakarta.

\section{B. Artikel Jurnal}

Cappelletti, Mauro, et. al., "Access To Justice: Comparative General Report", International Private Law, 1976.

Chilton, Stephen dan Cuzzo, Maria Stalzer Wyant, "Habermas's Theory of Communicative Action as a Theoretical Framework for Mediation Practice", Conflict Resolution Quarterly, Volume 22, Nomor 3, 2005.

Hardiman, Budi, "Etika Politik Habermas",
Makalah Seri Kuliah Umum, November, 2010 .

Vera, Dennis A de, "Habermas, Discourse Ethics, and Normative Validity", Kritike, Vol. 8, No. 2, Desember, 2014.

\section{Artikel dalam Ontologi dengan Editor}

Eriksson, Owen, 1999, “A Generic Communication Model Based On Habermas And Searle's Versions Of Speech Act Theory", dalam Goldkuhl, G et. al., (ed), 1999, Proceedings of the fourth International Workshop on the Language Action Perspective on Communication Modelling, LAP, Copenhagen.

Goldkuhl, G., 2000, "The Validity of Validity Claims: An Inquiry Into Communication Rationality", dalam Schoop, Mareike dan Quix, Christoph (ed), 2000, Proceedings Of The Fifth International Workshop On The Language-Action Perspective on Communication Modelling, LAP, Aachen.

\section{Internet}

Bohman, James dan Rehg, William, "Jürgen Habermas", https://plato.stanford.edu/ archives/fall2017/entries/habermas/, diakses 9 Januari 2019. 